http://www.jfas.info

\title{
EVALUATING THE EFFECT OF AQUEOUS EXTRACT OF THE ROOTS OF NATIVE EDIBLE ASPARAGUS IN IRAN (ASPARAGUS OFFICINALIS L) ON THE CONCENTRATION OF LIVER FACTORS IN MALE RATS TREATED WITH CADMIUM CHLORIDE
}

\author{
H. A. Abedi ${ }^{1}$, H. K. Jahromi ${ }^{1, *}$, N. Sadeghi ${ }^{1}$, S. P. Amjadi ${ }^{2}$ and Z. K. Jahromi ${ }^{1}$ \\ ${ }^{1}$ Research center for non.Communicable Diseases, Jahrom University of Medical \\ Sciences, Jahrom, Iran \\ ${ }^{2}$ Jahrom University of Medical Sciences,Jahrom, Iran
}

Published online: 15 June 2016

\begin{abstract}
:
Introduction: Cadmium is of the environmental pollutants and is considered as a part of the list of 126 top elements of environmental pollutants which has a long half-life in the body and is estimated at about 10 to 30 years. The use of herbal medicines because of having many antioxidants and lack of side effects is increasing in the today world to be a good alternative for chemical drugs. So the objective of the present study is to evaluate the effect of aqueous extract of the root of native edible asparagus in Iran (Asparagus officinalis L.) on the concentration of liver enzymes in male rats exposed to cadmium chloride.

Method: 72 male rats were accidentally divided into the control, sham and test groups (100 $\mathrm{mg} / \mathrm{kg}$ asparagus extract, $200 \mathrm{mg} / \mathrm{kg}$ asparagus extract, $400 \mathrm{mg} / \mathrm{kg}$ asparagus extract, $5 \mathrm{mg} / \mathrm{kg}$ cadmium chloride, cadmium chloride and $100 \mathrm{mg} / \mathrm{kg}$ asparagus extract, cadmium chloride and
\end{abstract}

\footnotetext{
Author Correspondence, e-mail: hossein.kargarjahromy@yahoo.com doi: http://dx.doi.org/10.4314/jfas.v8i2s.161
} 
$200 \mathrm{mg} / \mathrm{kg}$ asparagus extract, cadmium chloride and $400 \mathrm{mg} / \mathrm{kg}$ asparagus extract). All injections were performed by gavage for 28 consecutive days. One-Way ANOVA and Duncan at the significance level of $5 \%$ were used for statistical analysis.

Results: Cadmium chloride increased the averages of serum ALT, AST, ALP and bilirubin significantly and decreased the averages of serum albumin and total protein significantly. Two doses of 200 and 400 of asparagus extract reduced the averages of serum ALT, AST and ALP significantly compared to the group which received cadmium chloride and each three doses of asparagus extract could reduce bilirubin concentration significantly compared to the group which received cadmium chloride. Two doses of 200 and 400 asparagus extract increased the averages of serum albumin and total protein significantly compared to the receivers of cadmium chloride.

$400 \mathrm{mg} / \mathrm{kg}$ asparagus extract had the greatest effect on improving and adjusting the studied liver parameters.

Conclusion: The extract of asparagus root has probably improved the destructive effects of cadmium chloride due to abundant antioxidant property. Of course, $400 \mathrm{mg}$ dose has had the most effect in this study.

keywords: Cadmium chloride; roots of native edible.

\section{INTRODUCTION}

Edible asparagus (Asparagus officinalis L.) is a garden vegetable which is cultured in the areas with temperate and subtropical climates. Asparagus is herbaceous plant, perennial with two-bases from the order of asparagus, Asparagaceae and the genus Asparagus (1). Its leaves are squamous and narrow, long and green branches grow from their sides as three to eight batches. The genus Asparagus grows worldwide and east Mediterranean to the Caucasus Mountains are mentioned as the origin of this specious (2). There is a combination of potassium and a kind of amino acid with a diuretic effect and thus helps the excess body water to be excreted. Asparagus contains inulin (a carbohydrate) that is very beneficial for the digestive system. This type of carbohydrate causes growing up beneficial bacteria in the intestine such as 
lactobacillus and bifidobacteria (3). Asparagus also contains saponins as well as steroidal compounds which stimulate the secretion of lutein and steroidal hormones (4).

Liver is the center of body metabolism and many biochemical processes taking place there. Synthesis of bile and urea, storage of glycogen and some minerals and vitamins, detoxification, synthesis of protein and enzymes are the most important functions of liver and any disruption in the function of this vital organ causes a set of physiological and anatomical disorders as well as a variety of diseases (5).

Criteria for the diagnosis of liver injuries is based on biochemical reactions. Evaluation and measurement of serum levels of liver intracellular enzymes has been introduced as a diagnostic criterion in hepatocytes' destruction. Liver damage can lead to the leakage of these enzymes from the hepatocytes and their excessive entry into the blood. Therefore, liver damage can be realized by measuring these enzymes in the blood (6). Three enzymes of aspartate aminotransferase (AST or SGOT), alanine aminotransferase (ALT or SGPT) and alkaline phosphate (ALP) are the most important of these enzymes. Aminotransferases transfer an amine factor from a donor molecule to a receptor molecule in protein metabolism (7). The aspartate aminotransferase enzyme (AST) is found in all body cells particularly heart, liver, skeletal muscle and kidney cells. Alanine aminotransferase (ALT) is also found naturally in the liver. Although it cannot be said that this enzyme is exclusively in the liver, but liver is the place where the enzyme is most concentrated and therefore is a more specific marker for liver damage (7). Alkaline phosphatase enzyme (ALP) is also available in some important body tissues such as liver, bone, kidney and placenta of the pregnant women, but much of it is found in the liver and bone (8).

Increasing concentrations of bilirubin and decreased total protein and serum albumin are also considered as the other main indicators of liver injury $(9,10)$.

In the conducted study, it was determined that asparagus contains much of $\mathrm{C}, \mathrm{B}, \mathrm{A}, \mathrm{E}$ and $\mathrm{K}$ vitamins as well as calcium, zinc, fiber and folate (vitamin B9). Folate of asparagus causes that the use of this plant during pregnancy reduces congenital malformations. Eating asparagus can also help to boost sexual drive (11) and stimulates the secretion of luteal hormones and progesterone (4). Studies show that asparagus can treat the weakness of urinary bladder, is 
useful for strengthening the heart, cures jaundice, fatigue and liver toxicity (12), and is laxative and treatment of bowel pain (13). Other researches indicate that this plant is hematopoietic due to having chlorophyll and anemic people should take advantage of this plant (14). Asparagus contains other antioxidant and anticancer compounds such as aspargine, ...Ferrin, inositol, tannin, gallic acid, asparagus and succinic acid, rutin, protoducin, flavonoid and saponins (15). Other conducted studies showed that the extract of this plant contains amino acids and minerals which can help to counteract the drowsiness and malaise (16).

Cadmium is one of the most important industrial and environmental pollutants that has many effects on its surrounding area. This toxic and heavy metal easily absorbed by plants, animals and micro-organisms and can cause acute cellular and tissue injuries in alive creatures (17). Inhaling polluted air and cigarette smoke leads to respiratory infection of this metal in humans. In total, food and cigarette smoke are known as the greatest sources of human exposure to cadmium $(17,18)$. Intracellular accumulations of cadmium lead to creation of lesions in organs such as liver, kidney, lung, brain, testes, placenta, ovary and etc $(18,19)$.

Cadmium induces and increases the production of oxygen free radicals in the cells. On the other hand, by reducing intracellular antioxidants and disturbing the balance between antioxidants and cellular oxidizing agents, damages to the valuable vital molecules such as enzyme, protein and membrane lipids (20). The best way to deal with it, is an increase in antioxidant compounds in cell and increased cell survival time to cadmium toxicity. It seems that antioxidant agents can inhibit cadmium in the blood by binding to it or reduce its harmful effects by blocking its intracellular activity (20).

Cadmium enters to the food chain through various ways including water and soil (21). Oxidative lesions in the tissues are of the early signs of cadmium toxicity while cancerogenic effects are considered as chronic toxicity of cadmium. Due to the ability to produce large quantities of a protein binding to the metals especially cadmium, liver is the most important organ in toxicity with this heavy metal (22). Induction of acute experimental hepatic and renal toxicities by cadmium administration, have been proven in laboratory animals $(23,24)$. Recently, the strategies of prevention and treatment of cadmium toxicity has been focused on the use of chemical compounds derived from plants (22). 
Cadmium is one of environmental pollutants and is considered as a part of the list of 126 top environmental pollutants. Workers of batteries industry, paint manufacturing, oil producing, melting of metals and mines are at the expose of this metal (25). The smoke of forest fires and volcanic gases are considered as the major sources of air pollution and the wind is also effective in spreading it to the other areas. Thus, inhalation of polluted air and cigarette smoke leads to respiratory infection of this metal in humans $(25,26)$. In total, food and cigarette smoke are known as the biggest sources of human exposure to cadmium (26). While the half-life of cadmium is long in the body and is estimated to be about 10 to 30 years (19). Using herbal medicines is increasing in the today world because of having abundant antioxidants and lack of side effects to be a suitable alternative for chemical drugs. So, the objective of the present study is to evaluate the effect of aqueous extract of edible root of asparagus native in Iran (Asparagus officinalis L.) on liver enzymes concentrations in male rats exposed to cadmium chloride.

\section{METHOD}

This research is an experimental study and all ethical issues about the way to work with laboratory animals were considered. These issues with the code IR.JUMS.REC.1394.111 have been approved by the Ethics Committee of Jahrom University of Medical Sciences. To conduct this study, adult male Wistar rats with an average weight of 180-200 were used. The rats were kept in animal breeding room in Jahrom University of Medical Science to adapt. Bright and dark cycle was included 12 hours of light and 12 hours of darkness at $23 \pm 1$ temperature and humidity of about 50-55\%. Animals had free access to food and water. The total number of mice were 72 male rats which were accidentally divided into 9 groups of 8 animals. According to the previous papers, the aqueous extract concentration of asparagus root has been determined as 100, 200 and $400 \mathrm{mg} / \mathrm{kgbw}$ (27). Also, according to the previous articles, the concentration of injected cadmium chloride is determined as $5 \mathrm{mg} / \mathrm{kg}$ which its solvent was distilled water and was administered by gavage (28).

So the control and test groups were included the below groups in this study:

Control group: this group did not receive any treatment during the test (28 days) $(n=8)$. 
Sham group: this group received distilled water as gavage according to the body weight during test (28 days) $(\mathrm{n}=8)$.

Test 1 group (Asp $\left.\mathbf{A s 0}_{10}\right)$ : this group received the aqueous extract of asparagus root with the concentration of $100 \mathrm{mg} / \mathrm{kg}$ for 28 days as gavage and according to body weight (gavage) in 0.2 $\operatorname{cc}(n=8)$.

Test 2 group (Asp200): this group received the aqueous extract of asparagus root with the concentration of $200 \mathrm{mg} / \mathrm{kg}$ for 28 days as gavage and according to body weight (gavage) in 0.2 $\mathrm{cc}(\mathrm{n}=8)$.

Test 3 group $\left(\mathbf{A s p}_{400}\right)$ : this group received the aqueous extract of asparagus root with the concentration of $400 \mathrm{mg} / \mathrm{kg}$ for 28 days as gavage and according to body weight (gavage) in 0.2 $\mathrm{cc}(\mathrm{n}=8)$.

Test 4 group $\left(\mathbf{C}_{\mathbf{a}} \mathbf{C l}_{2}\right)$ : this group received $5 \mathrm{mg} / \mathrm{kg}$ cadmium chloride solved in $0.2 \mathrm{ml}$ of distilled water as gavage, for 28 days and in accordance with the body weight $(n=8)$.

Test 5 group $\left(\mathbf{A s p}_{100}+\mathbf{C}_{\mathbf{a}} \mathbf{C l}_{2}\right)$ : this group received $100 \mathrm{mg} / \mathrm{kg}$ aqueous extract of asparagus root (gavage) in $0.2 \mathrm{cc}+5 \mathrm{mg} / \mathrm{kg}$ cadmium chloride solved in $0.2 \mathrm{ml}$ of distilled water (gavage) for 28 days and in accordance with the body weight $(n=8)$.

Test 6 group $\left(\mathbf{A s p}_{\mathbf{2 0 0}}+\mathbf{C}_{\mathbf{a}} \mathbf{C l} \mathbf{2}_{2}\right)$ : this group received $200 \mathrm{mg} / \mathrm{kg}$ aqueous extract of asparagus root (gavage) in $0.2 \mathrm{cc}+5 \mathrm{mg} / \mathrm{kg}$ cadmium chloride solved in $0.2 \mathrm{ml}$ of distilled water (gavage) for 28 days and in accordance with the body weight $(n=8)$.

Test 7 group $\left(\mathbf{A s p}_{\mathbf{4 0 0}}+\mathbf{C}_{\mathbf{a}} \mathbf{C l} \mathbf{2}\right)$ : this group received $400 \mathrm{mg} / \mathrm{kg}$ aqueous extract of asparagus root (gavage) in $0.2 \mathrm{cc}+5 \mathrm{mg} / \mathrm{kg}$ cadmium chloride solved in $0.2 \mathrm{ml}$ of distilled water (gavage) for 28 days and in accordance with the body weight $(n=8)$.

At the end of research (day $29^{\text {th }}$ ), blood was taken directly from the animals' heart by a $5 \mathrm{cc}$ syringe (anesthetized by ether) and their serums were harvested after centrifuge (for 15 minutes and in 3000 r.p.m) and stored at $-20^{\circ} \mathrm{C}$ refrigerator till the test time. Pars Azmoon kits were used to measure ALT, AST, ALP, Albumin, Total protein and Bilirubin. 


\section{RESULTS}

\section{The effect of hydro alcoholic extract of asparagus on serum levels of the liver enzymes, total protein and bilirubin}

Hydro alcoholic extract of asparagus with concentration of 200 and $400 \mathrm{mg}$, reduced each three enzymes of ALT, AST and ALP significantly compared to the control and sham groups. The group treated by cadmium chloride caused a significant increase in the amounts of these enzymes. Treating groups with cadmium chloride and asparagus extract with the concentrations of 200 and $400 \mathrm{mg}$ caused a significant decrease in amounts of liver enzyme compared with cadmium chloride group. But treatment groups of cadmium chloride with 200 and $400 \mathrm{mg}$ asparagus extract showed a significant increase in amount of enzymes compared to the control and sham group.

The greatest effect was related to $400 \mathrm{mg}$ dose of asparagus root extract (table 1).

The effect of hydro alcoholic extract of asparagus on total protein (TP) and albumin: asparagus hydro alcoholic extract with concentrations of 200 and $400 \mathrm{mg}$ increased TP significantly compared to the control and sham groups but only its $400 \mathrm{mg}$ concentration caused a significant increase in albumin compared to the control and sham groups. Treatment groups of cadmium chloride with 200 and $400 \mathrm{mg}$ asparagus extract caused a significant increase in TP and albumin compared to cadmium chloride group. But the treatment group of cadmium with $200 \mathrm{mg}$ asparagus extract showed a significant decrease in TP and albumin compared to the control and sham groups. Treatment group of cadmium chloride with $400 \mathrm{mg}$ asparagus extract showed an insignificant difference in TP and albumin amounts compared to the control and sham groups (table 1).

The effect of hydro alcoholic extract of asparagus on bilirubin (Br): treating group with cadmium chloride caused a significant increase in bilirubin. Treatment groups of cadmium chloride with 100, 200 and $400 \mathrm{mg}$ asparagus extracts caused a significant decrease in bilirubin compared to cadmium chloride group. But treatment groups of cadmium chloride with 100 and $200 \mathrm{mg}$ asparagus extract showed a significant increase in bilirubin compared to the control and sham groups. Treatment group of cadmium chloride with $400 \mathrm{mg}$ asparagus extract showed an insignificant difference of bilirubin amount compared to the control and sham groups (table 1) 
Results of the studied groups in terms of biochemical parameters

\begin{tabular}{|c|c|c|c|c|c|c|}
\hline Variables & $\begin{array}{l}\mathbf{A S T} \\
(\mathrm{U} / \mathrm{L})\end{array}$ & $\begin{array}{l}\text { ALT } \\
(\mathrm{U} / \mathrm{L})\end{array}$ & $\begin{array}{l}\mathbf{A L P} \\
(\mathrm{U} / \mathrm{L})\end{array}$ & $\begin{array}{c}\mathbf{T P} \\
(\mathrm{g} / \mathrm{dl})\end{array}$ & $\begin{array}{c}\text { Alb } \\
(\mathrm{g} / \mathrm{dl})\end{array}$ & $\begin{array}{c}\mathbf{B r} \\
(\mathrm{mg} / \mathrm{dl})\end{array}$ \\
\hline \multicolumn{7}{|l|}{ Groups } \\
\hline Control & $0.9 \pm 0.1$ & $5 \pm 0.1$ & $8 \pm 0.2$ & $245 \pm 7.5$ & $113 \pm 3.5$ & $183 \pm 2.2$ \\
\hline Sham & 0.9 & $5 \pm 0.2$ & $7.9 \pm 0.3$ & $235 \pm 7$ & $120 \pm 2.3$ & $184 \pm 2.2$ \\
\hline $\mathbf{A s p}_{100}$ & 0.8 & $5 \pm 0.1$ & $8.2 \pm 0.2$ & $228 \pm 5$ & $115 \pm 4.2$ & $173 \pm 3.1$ \\
\hline $\mathbf{A s p}_{200}$ & 0.8 & $5 \pm 0.1$ & $8.6 \pm 0.2^{*}$ & $227 \pm 5.4^{*}$ & $100 \pm 3.8^{*}$ & $142 \pm 1.3^{*}$ \\
\hline $\mathbf{A s p}_{400}$ & 0.8 & $6 \pm 0.2^{*}$ & $9 \pm 0.2^{*}$ & $197 \pm 6^{*}$ & $87 \pm 1.7^{*}$ & $125 \pm 2.4^{*}$ \\
\hline $\mathrm{C}_{\mathrm{a}} \mathrm{Cl}_{2}$ & $2^{*}$ & $3 \pm 0.1^{*}$ & $4.8 \pm 0.1^{*}$ & $485 \pm 7^{*}$ & $339 \pm 5^{*}$ & $444 \pm 6.2^{*}$ \\
\hline $\begin{array}{c}\mathrm{Asp}_{100^{+}} \\
\mathrm{C}_{\mathrm{a}} \mathrm{Cl}_{2}\end{array}$ & 1.7 & 3 & $5 \pm 0.1$ & $463 \pm 5.2$ & $330 \pm 5$ & $433 \pm 4.4$ \\
\hline $\begin{array}{c}\mathrm{Asp}_{200}+ \\
\mathrm{C}_{\mathrm{a}} \mathrm{Cl}_{2}\end{array}$ & 1 & $4 \pm 0.1$ & $6 \pm 0.1$ & $419 \pm 5.1$ & $293 \pm 4.7$ & $381 \pm 7.4$ \\
\hline $\begin{array}{c}\mathrm{Asp}_{400}+ \\
\mathrm{C}_{\mathrm{a}} \mathrm{Cl}_{2}\end{array}$ & 0.9 & $4.9 \pm 0.1$ & $7.8 \pm 0.1$ & $346 \pm 11.4$ & $184 \pm 4.6$ & $313 \pm 7.4$ \\
\hline
\end{tabular}

*The difference with control and sham groups is significant.

The difference with the receiver group of cadmium chloride is significant

ASP: Asparagus

AST: Aspartate Amino Transferase

ALT: Alanine Amino Transferase

ALP: Alkaline Phosphatase

TP: Total Protein

ALb: Albumine

Br: Bilirobine

\section{DISCUSSION}

Cadmium is one of the heavy metals which is widely used in various industries including galvanization, dyeing, plastics and battery. This metal is one of the important environmental and industrial pollutants. The studies have shown that the compounds of this metal has significant undesirable effects on different organs of human and animals (29). Liver and kidney 
are of the main body organs that about $50 \%$ of cadmium is accumulated there due to the high concentrations of melatonin in them (30) and thus are under the influence of cadmium more than the other organs. According to another study, cadmium accumulation in these organs due to the defects in renal excretion system increases with age (18). In cells lacking metallothionein, mitochondria are the main place of biochemical damages of cadmium (31). Increased bilirubin, decreased total protein and albumin indicate damage and a disruption in the normal function of liver (32). Another indicator to evaluate the amount of liver toxicity is measuring ALT, AST and ALP enzymes which usually increase during the liver injury caused by changes in cell morphology structure and membrane rupture (33).

Researchers have showed that in non-alcoholic liver diseases, oxidative stress and lipid peroxidation are the key factors of damage to cells. The content of cytochrome P450 usually decreases in this condition and its indicator is the increased expression of mRNA and protein level of cyp2E1 (one of P450 system enzymes) which resulted in accelerated oxidative stress (34). Also in 1980, a study was conducted on several different cells that showed the most affected organelle by the cadmium toxicity is the nucleius and its inner RNA (35). The damage rate depends on a number of factors such as: the level of cell activity, cadmium concentration, the time which the cells are exposed to cadmium and cell defense mechanisms (17). Also, it has been proven that cadmium increases the production of free radicals in cells by interfering with antioxidant enzymes, removing sulfhydryl groups' bands by glutathione and substitution with copper, zinc and iron in proteins and reduces some antioxidants such as catalase, Super Oxide Dismutase (SOD) and glutathione reductase and glutathione peroxidase due to having thiols and causes lipid peroxidation (20). This causes impairing cell growth and differentiation, inhibiting apoptotic mechanisms, blocking repair mechanisms of DNA, signaling pathway and gene expression (36).

Due to the adverse effects of cadmium on liver and creating oxidative stress, the objective of our study was to evaluate the preventive and antioxidant effects of edible asparagus plant on liver toxicity due to this metal on male rats. In the present study, cadmium increased the level of liver enzymes and bilirubin and reduced albumin and total protein compared to the sham and 
control groups. Asparagus extract causes a decrease in liver enzymes, bilirubin and an increase in albumin and total protein in treated groups with cadmium chloride.

Researchers showed previously that asparagus root contains steroidal saponins, alkaloid, flavonoids, sterol, terpenes, tannins, phenols, mucilage and vitamin E (37). Flavonoids, saponins, polyphenols and vitamin $\mathrm{E}$ are able to collect free radicals such as hydroxyl and anion of super oxide dismutase and inhibit lipid peroxidation (38). It is also shown that antioxidant enzymes activities of super oxide dismutase and catalase in the liver of hypercholesteremic mice which are treated by asparagus, are increased which is due to flavonoids' role and the available polyphenols in this plant in improving oxidative stress (16).

According to the report that asparagus also has flavonoids, the protective effects observed in our study are likely due to its antioxidant activity and prevention of oxidative stress effects on the membrane of liver cells. It was observed in this research that asparagus has a dose-dependent effect and its highest dose $(400 \mathrm{mg})$ has created the best protective effect, so it can be concluded that the best answer in this dose is probably due to high concentration of available antioxidants in this extract and restoring a better balance between oxidants and antioxidants.

Supporting this theory, researchers have shown that using the alcoholic extract of S_brevistigma and rose due to having flavonoid compounds protects the liver against toxic effects of carbon tetrachloride or galactosamine and lipopolysaccharide through reducing the amounts of liver enzymes and increasing lipid peroxidation $(10,16)$. Reduced bilirubin and enzymes in the treated groups with extract showed the return of normal liver function. These evidences indicate that asparagus extract not only prevent the bad effects of oxidative stress, but also it is likely that asparagus extract could generate new and healthy cells. The probable mechanism of this effect can be attributed to the role of antioxidants in preventing the damage of cellular oxidizing agents to the nucleus and mitochondria which leads to dysfunction of cytochrome $\mathrm{P} 450$ or protein synthesis and cell growth regulation (34). These effects may be due to the presence of other compounds in asparagus extract such as tannins, saponins, vitamin E and alkaloids because it has already be proven that asparagus extract can increase the number of follicle graphs in the ovaries of rats (12). Therefore, it is recommended that this issue be 
examined in future works. Another factor that asparagus extract can protect cells because of several antioxidants is inhibition of P450 system enzymes and the control of this claim is the studies which showed that cyp2E1 inhibitors such as dially sulfide in garlic, phenyethyl isothiocyanate and sulforaphane in cruciferous vegetables, bergamottin in grapes and orange can reduce liver toxicity (34). Antioxidant compounds in asparagus may also have some effects that can be considered in the future.

\section{CONCLUSION}

Asparagus extract in a dose-dependent manner could prevent the destructive effects of oxidative stress resulted from hepatotoxicity due to the exposure with cadmium chloride. These effects are resulted from its antioxidant role due to the presence of some compounds such as flavonoids.

\section{ACKNOWLEDGEMENT}

This article is derived from the research project in Jahrom University of Medical Science which is approved as the M.D. thesis of Mr. Seyed Payam Amjadi. So, we highly appreciate the kind assistance of the Deputy of Research to conduct it.

\section{REFRENCES}

1. Rubatzky VE, Yamaguchi M. World vegetables: principles, production, and nutritive values: Springer Science \& Business Media; 2012.

2. Štajner N, Bohanec B, Javornik B. Genetic variability of economically important Asparagus species as revealed by genome size analysis and rDNA ITS polymorphisms. Plant Science. 2002;162(6):931-7.

3. Moreno R, Espejo J, Cabrera A, Millan T, Gil J. Ploidic and Molecular Analysis of 'Morado de Huetor' Asparagus (Asparagus officinale L.) Population; A Spanish Tetraploid Landrace. Genetic Resources and Crop Evolution. 2006;53(4):729-36.

4. KargarJahromi Hossein KJHA, KargarJahromi Zahra ,KhabbazKherameh Zahra. The effect of the aqueous root extract of edible asparagus native to Iran on 
serum progesterone and LH levels in adult female rats. Journal of Jahrom University of Medical Sciences. 2015;13(2).

5. Androli T, Carpenter C, Griggs R, Benjamin I. Diseases of the liver and biliary system. Cecil's Essentials of Medicine 7th ed USA: WB Saunders Company. 2007;23.

6. Ajayi OB ,Odutuga A. Effect of low-zinc status and essential fatty acids deficiency on the activities of aspartate aminotransferase and alanine aminotransferase in liver and serum of albino rats. Food/Nahrung. 2004;48(2):88-90.

7. Aniya Y, Koyama T, Miyagi C, Miyahira M, Inomata C, Kinoshita S, et al. Free radical scavenging and hepatoprotective actions of the medicinal herb, Crassocephalum crepidioides from the Okinawa Islands. Biological and Pharmaceutical Bulletin. 2005;28(1):19-23.

8. Kaneko JJ, Harvey JW, Bruss ML. Clinical biochemistry of domestic animals: Academic press; 2008.

9. Jayasekhar P, Mohanan P, Rathinam K. Hepatoprotective activity of ethyl acetate extract of Acacia catechu. Indian Journal of Pharmacology. 1997;29(6):426.

10. Singh D, Mehta S, NEOLIYA NK, SHUKLA YN, MISHRA M. Hepatoprotective activity of Sarcostemma brevistigma against carbon tetrachloride-induced hepatic damage in rats. Curr Sci. 2003;84:22-7.

11. Spada A, Caporali E, Marziani G, Portaluppi P, Restivo F, Tassi F, et al. A genetic map of Asparagus officinalis based on integrated RFLP, RAPD and AFLP molecular markers.

Theoretical and applied genetics. 1998;97(7):1083-9.

12. Karimi H, Kargar Jahromi H, Ranjbary AG, Kargar Jahromi Z, Khabbaz Kherameh Z. Effects of aqueous extract from Asparagus officinalis L. roots on hypothalamic-pituitary-gonadal axis hormone levels and the number of ovarian follicles in adult rats. International Journal of Reproductive BioMedicine. 2016;14(2):75-80.

13. Debella A, Haslinger E, Kunert O, Michl G, Abebe D. Steroidal saponins from Asparagus africanus. Phytochemistry. 1999 Aug;51(8):1069-75. PubMed PMID: 10444861.

14. Menassie G. The use and values of wild plant products to the people of Bale. Walia. 1991 (13):21-8. 
15. Woo WS, Lee EB, Kang SS, Shin KH ,Chi HJ. Antifertility principle of Dictamnus albus root bark. Planta medica. 1987 Oct;53(5):399-401. PubMed PMID: 3432420.

16. Visavadiya NP, Narasimhacharya AV. Asparagus root regulates cholesterol metabolism and improves antioxidant status in hypercholesteremic rats. Evidence-based complementary and alternative medicine : eCAM. 2009 Jun;6(2):219-26. PubMed PMID: 18955232. Pubmed Central PMCID: 2686619.

17. Ord MJ, Bouffler SD, Chibber R. Cadmium induced changes in cell organelles: an ultrastructural study using cadmium sensitive and resistant muntjac fibroblast cell lines. Archives of toxicology. 1988;62(2-3):133-45. PubMed PMID: 3196148.

18. Satarug S, Moore MR. Adverse health effects of chronic exposure to low-level cadmium in foodstuffs and cigarette smoke. Environmental health perspectives. 2004 Jul;112(10):1099-103. PubMed PMID: 15238284. Pubmed Central PMCID: 1247384.

19. Pari L, Murugavel P. Role of diallyl tetrasulfide in ameliorating the cadmium induced biochemical changes in rats. Environmental toxicology and pharmacology. 2005 Nov;20(3):493-500. PubMed PMID: 21783631.

20. Gurer H, Ercal N. Can antioxidants be beneficial in the treatment of lead poisoning? Free radical biology \& medicine. 2000 Nov 15;29(10):927-45. PubMed PMID: 11084283.

21. Ahmadizadeh M BA. Effect of Vit $\mathrm{K}$ in prevention against cadmium chloride implications in rat kidney and liver. Jondishapur medicine science magazine. 2005;6(4): , 404 - 13.

22. Murugavel P, Pari L. Effects of diallyl tetrasulfide on cadmium-induced oxidative damage in the liver of rats. Human \& experimental toxicology. 2007 Jun;26(6):527-34. PubMed PMID: 17698948.

23. Harstad EB, Klaassen CD. iNOS-null mice are not resistant to cadmium chloride-induced hepatotoxicity. Toxicology. 2002 Jun 14;175(1-3):83 .90-PubMed PMID: 12049838.

24. Karadeniz A, Cemek M, Simsek N. The effects of Panax ginseng and Spirulina platensis on hepatotoxicity induced by cadmium in rats. Ecotoxicology and environmental safety. 2009 Jan;72(1):231-5. PubMed PMID: 18395256. 
25. Aktas C, Kanter M, Erboga M, Ozturk S. Anti-apoptotic effects of curcumin on cadmium-induced apoptosis in rat testes. Toxicology and industrial health. 2012 Mar;28(2):122-30. PubMed PMID: 21632575.

26. Gouda SG, Khalil MS, Naim MM. Curcumin protects against testicular damage and genotoxicity induced by acrylamide in male albino mice. Egyptian Journal of Histology. 2011;34(2):333-45.

27. Zhu X, Zhang W, Zhao J, Wang J, Qu W. Hypolipidaemic and hepatoprotective effects of ethanolic and aqueous extracts from Asparagus officinalis L. by-products in mice fed a high-fat diet. Journal of the science of food and agriculture. 2010 May;90(7):1129-35. PubMed PMID: 20393993.

28. Renugadevi J, Prabu SM. Cadmium-induced hepatotoxicity in rats and the protective effect of naringenin. Experimental and toxicologic pathology : official journal of the Gesellschaft fur Toxikologische Pathologie. 2010 Mar;62(2):171-81. PubMed PMID: 19409769.

29. Nam $\mathrm{DH}$, Lee $\mathrm{DP}$. Monitoring for $\mathrm{Pb}$ and $\mathrm{Cd}$ pollution using feral pigeons in rural, urban, and industrial environments of Korea. The Science of the total environment. 2006 Mar 15;357(1-3):288-95. PubMed PMID: 16169573.

30. Joseph P. Mechanisms of cadmium carcinogenesis. Toxicology and applied pharmacology. 2009 Aug 1;238(3):272-9. PubMed PMID: 19371617.

31. Jamall IS, Sprowls JJ. Effects of cadmium and dietary selenium on cytoplasmic and mitochondrial antioxidant defense systems in the heart of rats fed high dietary copper. Toxicology and applied pharmacology. 1987 Jan;87(1):102-10. PubMed PMID: 3798447.

32. Obi E, Orisakwe O, Asomugha L, Udemezue O, Orish V. The hepatotoxic effect of halofantrine in guinea pigs. Indian journal of pharmacology. 2004;36(5):303.

33. Jimoh F, Odutuga A. Histological changes in the lungs and heart due to dietary oxidized groundnut oil. Nig J Biochem Mol Biol. 2002;17:1-5.

34. Lu Y, Cederbaum AI. CYP2E1 and oxidative liver injury by alcohol. Free Radical Biology and Medicine. 2008;44(5):723-38. 
35. Puvion E, Lange M. Functional significance of perichromatin granule accumulation induced by cadmium chloride in isolated rat liver cells. Experimental cell research. 1980 Jul;128(1):47-58. PubMed PMID: 7408986.

36. Bishak YK, Payahoo L, Osatdrahimi A, Nourazarian A. Mechanisms of cadmium carcinogenicity in the gastrointestinal tract. Asian Pac J Cancer Prev. 2015;16:9-21.

37. Gupta A, Tandon N. Reviews on Indian medicinal plants. 2004.

38. Rice-Evans CA, Miller NJ, Bolwell PG, Bramley PM, Pridham JB. The relative antioxidant activities of plant-derived polyphenolic flavonoids. Free radical research. 1995 Apr;22(4):375-83. PubMed PMID: 7633567

\section{How to cite this article:}

Abedi H A, Jahromi H K, Sadeghi N, Amjadi S P and Jahrom Z K. Evaluating the effect of aqueous extract of the roots of native edible asparagus in iran (asparagus officinalis $l$ ) on the concentration of liver factors in male rats treated with cadmium chloride. J. Fundam. Appl. Sci., 2016, 8(4S), 2008-2022. 